\title{
Thermal tolerance in embryos and larvae of the bay scallop Argopecten irradians under simulated power plant entrainment conditions*
}

\author{
D. A. Wright ${ }^{1}$, W. H. Roosenburg ${ }^{1}$ and M. Castagna ${ }^{2}$ \\ ${ }^{1}$ University of Maryland, Center for Environmental and Estuarine Studies, Chesapeake Biological Laboratory, Solomons, \\ Maryland 20688, USA \\ ${ }^{2}$ Virginia Institute of Marine Science, Eastern Shore Laboratory, Wachapreague, Virginia 23480, USA
}

\begin{abstract}
Thermal tolerance was tested in cleavage stages, trochophores and straight hinge larvae of the bay scallop Argopecten irradians. Experiments were designed to simulate larval entrainment in power plant cooling systems. An 11 (temperature) $\times 8$ (time) matrix was used with temperatures ranging from 20.6 to $43.0^{\circ} \mathrm{C}$ and exposure times from $1 \mathrm{~min}$ to $6 \mathrm{~h}$. Pooled mortality data from triplicate experiments for each larval stage were subjected to stepwise regression analysis ( $\sqrt{\text { arcsine \% mortality }}$ on temperature and time). Equations derived from these analyses, comprising first, second and third order terms for temperature and time, were used to generate response surfaces relating mortality to temperature and exposure time. In general, higher mortalities were associated with higher temperatures and with longer time exposure at any one temperature. However, there was some evidence of cold shock in trochophore and straight hinge larvae, with elevated mortalities occurring at temperatures lower than the spawning temperature. There was a trend towards increased thermal tolerance in older larvae, although in general A. irradians showed the greatest sensitivity to thermal shock of the estuarine bivalves so far tested in our laboratory.
\end{abstract}

\section{INTRODUCTION}

Increasing demand for electricity has prompted the consideration of estuarine and marine coastal sites for both fossil fuel and nuclear power plants (e.g. Tarzwell, 1972). This in turn has led to concern over the effects on marine and estuarine animals of heated water discharged from the condenser tubes and of heat exposure to entrained larvae.

The biological problems involved are complex and various. While some investigations have concentrated on possible effects of the thermal plume on the adjacent water body (e.g. Wallis, 1977; Lucas and Costlow, 1979) others have focused on the more severe temperature shock encountered by fish and invertebrate larvae entrained in the cooling complex (Kennedy et al., 1974a, b; Koo and Johnston, 1978). Such organisms, when drawn into the condenser cooling system will experience a sudden rise in temperature $(\Delta T)$ averaging $10.8 \mathrm{C}^{\circ}$ (Coutant, 1970) and after a short expo-

- Contribution No. 1448 of the University of Maryland Center for Environmental and Estuarine Studies sure will be subjected to a cold shock when the water is returned to the environment. This phenomenon may result in severe mortality among species in the vicinity of a power plant (Marcy, 1971), with various economic and ecological effects. To predict the impact of steam electric generating plants on the estuarine environment it is necessary to obtain temperature-time tolerance data for a wide variety of meroplanktonic organisms. The experimental design must reflect the acute and transient temperature changes likely to occur during the entrainment process and earlier investigations at this laboratory have obtained temperature-time mortality data for the coot clam Mulinia lateralis (Kennedy et al., 1974a) and the hard clam Mercenaria mercenaria (Kennedy et al., 1974b).

In the current study, temperature-time relations for survival of embryos and larvae of the bay scallop Argopecten irradians are investigated.

\section{MATERIALS AND METHODS}

Argopecten irradians were spawned at the Wachapreague Laboratory in vessels where tidal action was 
simulated by alternately raising and lowering the water level in the vessels. Temperature was allowed to fluctuate between 26 and $28^{\circ} \mathrm{C}$. The bay scallop is hermaphroditic, first ejecting sperm, later eggs. The spawning reaction to simulated current may represent a means of avoiding self-fertilization. Sperm of up to 13 individuals and eggs of 4 to 15 specimens were used to provide genetic diversity (Calabrese and Davis, 1970). Three developmental stages were used: cleavage stages ( 1 to $3 \mathrm{~h}$ ), trochophore larvae (9 to $11 \mathrm{~h}$ ) and straight hinge larvae (24 to $50 \mathrm{~h}$ ). Brood stock came from scallops reared at the Wachapreague hatchery and held in the natural environment near the Wachapreague Laboratory.

Clarified, ultraviolet-irradiated sea water of 28 to $31 \%$ salinity was used in all experiments. The cast aluminium experimental block bored to hold $882.5-\mathrm{cm}$ test tubes in an $8 \times 11$ matrix has been described by Hidu et al. (1974). Cold water was circulated in one side of the block and warm water at the opposite end, thereby creating a stable thermal gradient along the longer axis with a difference of 2.0 to $2.7 \mathrm{C}^{\circ}$ between each of the 11 ranks of tubes. Experimental temperatures varied between 20.4 and $43.1^{\circ} \mathrm{C}$. Temperature variation within a rank was rarely more than $0.3 \mathrm{C}^{\circ}$.

The 88 test tubes in the block were filled with $26 \mathrm{ml}$ water and allowed to stabilize at the various experimental temperatures. Four $\mathrm{ml}$ of water containing about 300 larvae were injected into each tube, using a device which insured that each row was injected simultaneously (Hidu et al., 1974). A single row of tubes, one tube from each of the 11 experimental temperatures was removed after $1,5,10,30,60,120$, 180 and $360 \mathrm{~min}$, representing a total of 88 different temperature-time combinations.

After their respective exposure time each batch of larvae was immediately transferred to containers at $26^{\circ} \mathrm{C}$ where they were allowed to incubate further. This incubation period allowed surviving cleavage stages and trochophore larvae to develop to a shelled stage where they could be preserved for later counting. For experiments with straight-hinge larvae, this further incubation period allowed dead animals to be eater out by bacteria, thereby enabling dead to be distinguished from live animals after preservation. In all cases preservation was accomplished in $1 \%$ buffered formalin $(0.38 \%$ formaldehyde). Experiments on each of the 3 developmental stages were conducted in triplicate. Percent mortality in cleavage and trochophore larvae was computed by comparing numbers of survivors of the test treatment with control animals inoculated into tubes maintained at spawning temperature outside the block.

For short-term exposures the injected water (at 26.6 $6^{\circ}$ ) containing the larvae, had a small effect on the temperature exposure experienced by these animals and some adjustment to recorded temperatures was made to offset this influence (Tables 1 to 3) (Kennedy et al., 1974a).

After raw numbers were converted to percent mortality, a stepwise multiple regression analysis of transformed mortality on ( $\sqrt{\arcsin } \%$ ) (M) time and temperature $(\mathrm{T})$ was performed by computer using a program created by the Health Sciences Computing Facility, UCLA. Equations derived from this program were used to develop response surfaces. These predicted larval mortality for any temperature-time combination within the experimental range although, given the variability of the material, Kennedy et al. (1974a) have concluded that a difference of $<20 \%$ between treatments may not be meaningful. Data treatment differed from that employed in earlier papers (Kennedy, 1974a, b) insofar as only those data up to and including the first record of $100 \%$ mortality at each temperature were entered in

Table 1. Argopecten irradians. Average \% mortality in early cleavage stages under different temperature-time combinations. Values in parentheses corrected for influence of injection water at $26.6^{\circ} \mathrm{C}$

\begin{tabular}{|c|c|c|c|c|c|c|c|c|c|c|c|}
\hline \multirow{2}{*}{$\begin{array}{l}\text { Time } \\
\text { (min) }\end{array}$} & \multicolumn{11}{|c|}{ Temperature $\left({ }^{\circ} \mathrm{C}\right)$} \\
\hline & 20.6 & 22.9 & 25.1 & 27.3 & 29.5 & 31.5 & 34.0 & 36.3 & 38.5 & 40.7 & 43.0 \\
\hline 1 & $\begin{array}{c}0 \\
(21.9)\end{array}$ & $\begin{array}{c}0 \\
(23.5)\end{array}$ & 0 & 0 & 0 & $\begin{array}{c}0 \\
(30.6)\end{array}$ & $\begin{array}{c}0 \\
(33.1)\end{array}$ & $\begin{array}{c}6 \\
(34.7)\end{array}$ & $\begin{array}{c}43 \\
(36.7)\end{array}$ & $\begin{array}{c}100 \\
(38.4)\end{array}$ & $\begin{array}{r}98 \\
(40.0)\end{array}$ \\
\hline 5 & $\begin{array}{c}0 \\
(21.5)\end{array}$ & 12 & 0 & 0 & 0 & $\begin{array}{c}0 \\
(30.9)\end{array}$ & $\begin{array}{c}0 \\
(33.4)\end{array}$ & $\begin{array}{c}69 \\
(35.3)\end{array}$ & $\begin{array}{c}100 \\
(37.3)\end{array}$ & $\begin{array}{c}100 \\
(39.2)\end{array}$ & $\begin{array}{c}92 \\
(40.9)\end{array}$ \\
\hline 10 & $\begin{array}{c}0 \\
(21.2)\end{array}$ & 0 & 0 & 0 & 0 & 1 & 34 & $\begin{array}{c}99 \\
(35.5)\end{array}$ & $\begin{array}{c}100 \\
(37.5)\end{array}$ & $\begin{array}{c}99 \\
(39.5)\end{array}$ & $\begin{array}{r}98 \\
(41.4)\end{array}$ \\
\hline 30 & 0 & 0 & 0 & 4 & 16 & 33 & 100 & 100 & 100 & 100 & 100 \\
\hline 60 & 20 & 0 & 5 & 14 & 0 & 27 & 100 & 100 & 100 & 100 & 100 \\
\hline 120 & 17 & 17 & 16 & 14 & 5 & 50 & 100 & 99 & 100 & 100 & 100 \\
\hline 180 & 45 & 30 & 30 & 18 & 17 & 42 & 95 & 100 & 100 & 100 & 100 \\
\hline 360 & 0 & 0 & 0 & 0 & 0 & 37 & 98 & 100 & 99 & 98 & 99 \\
\hline
\end{tabular}


Table 2. Argopecten irradians. Average \% mortality in trochophore larval stage under different temperature-time combinations. Values in parentheses corrected for influence of injection water at $26.6^{\circ} \mathrm{C}$

\begin{tabular}{|c|c|c|c|c|c|c|c|c|c|c|c|}
\hline \multirow{2}{*}{$\begin{array}{l}\text { Time } \\
\text { (min) }\end{array}$} & \multicolumn{11}{|c|}{ Temperature $\left({ }^{\circ} \mathrm{C}\right)$} \\
\hline & 20.7 & 22.9 & 25.1 & 27.5 & 29.5 & 31.9 & 34.1 & 36.4 & 38.6 & 40.8 & 43.0 \\
\hline 1 & $\begin{array}{c}30 \\
(22.0)\end{array}$ & $\begin{array}{c}35 \\
(23.5)\end{array}$ & 20 & 0 & 0 & $\begin{array}{c}0 \\
(31.0)\end{array}$ & $\begin{array}{c}0 \\
(33.2)\end{array}$ & $\begin{array}{c}4 \\
(34.8)\end{array}$ & $\begin{array}{c}0 \\
(36.8)\end{array}$ & $\begin{array}{c}43 \\
(38.5)\end{array}$ & $\begin{array}{r}99 \\
(40.0)\end{array}$ \\
\hline 5 & $\begin{array}{r}0 \\
(21.6)\end{array}$ & 20 & 0 & 0 & 0 & $\begin{array}{c}0 \\
(31.3)\end{array}$ & $\begin{array}{c}0 \\
(33.5)\end{array}$ & $\begin{array}{r}8 \\
(35.4)\end{array}$ & $\begin{array}{c}51 \\
(37.4)\end{array}$ & $\begin{array}{c}100 \\
(39.3)\end{array}$ & $\begin{array}{c}100 \\
(40.9)\end{array}$ \\
\hline 10 & $\begin{array}{r}6 \\
(21.3)\end{array}$ & 5 & 4 & 0 & 0 & 0 & 0 & $\begin{array}{c}3 \\
(35.6)\end{array}$ & $\begin{array}{c}100 \\
\{37.6\}\end{array}$ & $\begin{array}{c}100 \\
(39.6)\end{array}$ & $\begin{array}{c}100 \\
(41.4)\end{array}$ \\
\hline 30 & 39 & 0 & 0 & 0 & 14 & 0 & 1 & 100 & 100 & 100 & 100 \\
\hline 60 & 0 & 0 & 6 & 0 & 0 & 0 & 3 & 100 & 100 & 100 & 100 \\
\hline 120 & 44 & 0 & 0 & 0 & 0 & 0 & 76 & 100 & 100 & 100 & 100 \\
\hline 180 & 21 & 5 & 0 & 0 & 0 & 22 & 100 & 100 & 100 & 100 & 100 \\
\hline 360 & 55 & 58 & 42 & 42 & 38 & 50 & 100 & 100 & 100 & 100 & 100 \\
\hline
\end{tabular}

the regression equation. This had the effect of steepening the slope at the upper end of the temperature-time exposure axes and provided a slightly more accurate picture of the time course of mortality than was available from earlier studies. However, this did not affect our comparison of current data with those obtained from Mercenaria mercenaria and Mulinia lateralis.

\section{RESULTS AND DISCUSSION}

The results indicate a direct relationship between mortality and temperature increase. At higher temperatures there was an increase in mortality with an increase in time of exposure. There was a slight indication of greater thermal sensitivity in the cleavage stages although this was not as marked as in Mercenaria mercenaria and Mulinia lateralis larvae (Kennedy et al., $1974 \mathrm{a}$, b). For each developmental stage the extent of mortality in triplicated experiments was consistent, the results are averaged in Tables 1 to 3 . Over the approximate 23 to $29 \mathrm{C}^{\circ}$ range (ranks 2 to 5 in the block) survival was high and did not differ significantly from the controls. Thus, it was concluded that there was no significant block-associated mortality.

First, second and third order terms for temperature and time together with all of their possible combinations were examined to provide a predictive equation describing percent mortality in terms of temperature and time of exposure. Only those variables with $f$ values corresponding to $P<5 \%$ were entered in the final equation. The program selected variables causing the greatest reduction in residual sum of squares until no further variables satisfied the acceptance criteria. The derived coefficients selected for each stage are presented in Table 4 and an analysis of variance associated with regression is shown in Table 5. Using these equations, response surfaces shown in Fig. 1 to 3 were generated from the back transformed percentages. For each stage the coefficient of determination

Table 3. Argopecten inadians. Average \% mortality in straight hinge veliger larvae at different temperature-time combinations. Values in parentheses corrected for influence of injection water at $27.0^{\circ} \mathrm{C}$

\begin{tabular}{|c|c|c|c|c|c|c|c|c|c|c|c|}
\hline \multirow{2}{*}{$\begin{array}{l}\text { Time } \\
(\mathrm{min})\end{array}$} & \multicolumn{11}{|c|}{ Temperature $\left({ }^{\circ} \mathrm{C}\right)$} \\
\hline & 20.6 & 22.9 & 25.1 & 27.3 & 29.4 & 31.8 & 34.0 & 36.2 & 38.5 & 40.6 & 42.9 \\
\hline 1 & $\begin{array}{c}3 \\
(21.9)\end{array}$ & $\begin{array}{c}0 \\
(23.5)\end{array}$ & 0 & 7.3 & 0 & $\begin{array}{c}5 \\
(30.9)\end{array}$ & $\begin{array}{c}0 \\
(33.1)\end{array}$ & $\begin{array}{c}0 \\
(34.6)\end{array}$ & $\begin{array}{c}8 \\
(36.7)\end{array}$ & $\begin{array}{c}11 \\
(38.3)\end{array}$ & $\begin{array}{c}13 \\
(39.9)\end{array}$ \\
\hline 5 & $\begin{array}{c}0.6 \\
(21.4)\end{array}$ & 3 & 0 & 3 & 0 & $\begin{array}{c}1.8 \\
(31.2)\end{array}$ & $\begin{array}{c}0 \\
(33.4)\end{array}$ & $\begin{array}{c}0.6 \\
(35.2)\end{array}$ & $\begin{array}{c}3 \\
(37.3)\end{array}$ & $\begin{array}{c}26.0 \\
(39.1)\end{array}$ & $\begin{array}{c}90.8 \\
(40.8)\end{array}$ \\
\hline 10 & $\begin{array}{c}5.2 \\
(21.2)\end{array}$ & 2.9 & 0 & 1.8 & 1.8 & 2.9 & 7.5 & $\begin{array}{c}6.4 \\
(35.4)\end{array}$ & $\begin{array}{c}9.5 \\
(37.5)\end{array}$ & $\begin{array}{c}88.5 \\
(39.4)\end{array}$ & $\begin{array}{c}100 \\
(41.3)\end{array}$ \\
\hline 30 & 0 & 8.7 & 0.6 & 1.8 & 0.6 & 5.2 & 5.2 & 8.7 & 100 & 100 & 100 \\
\hline 60 & 4.1 & 1.8 & 4.1 & 0 & 1.8 & 0.6 & 0 & 37.6 & 100 & 100 & 100 \\
\hline 120 & 2.9 & 12.2 & 1.8 & 0 & 4.1 & 2.9 & 0 & 96.6 & 100 & 100 & 99 \\
\hline 180 & 2.9 & 0.6 & 7.3 & 1.8 & 0 & 7.3 & 12.2 & 98 & 99 & 99 & 100 \\
\hline 360 & 0.6 & 0 & 0 & 0 & 0 & 0 & 5.2 & 99 & 98 & 100 & 100 \\
\hline
\end{tabular}


Table 4. Argopecten irradians. Statistics of multiple regression of percentage mortality on temperature and time. $M$, minutes; $T$, temperature $\left({ }^{\circ} \mathrm{C}\right.$ ); $b$, regression coefficient, $S_{b}$, standard error of $b ; R^{2}$, coefficient of determination (increases as new variable is added); $S_{r s}$ standard error of response surface (decreases as each new variable is added); b', standard partial regression coefficient (absolute values)

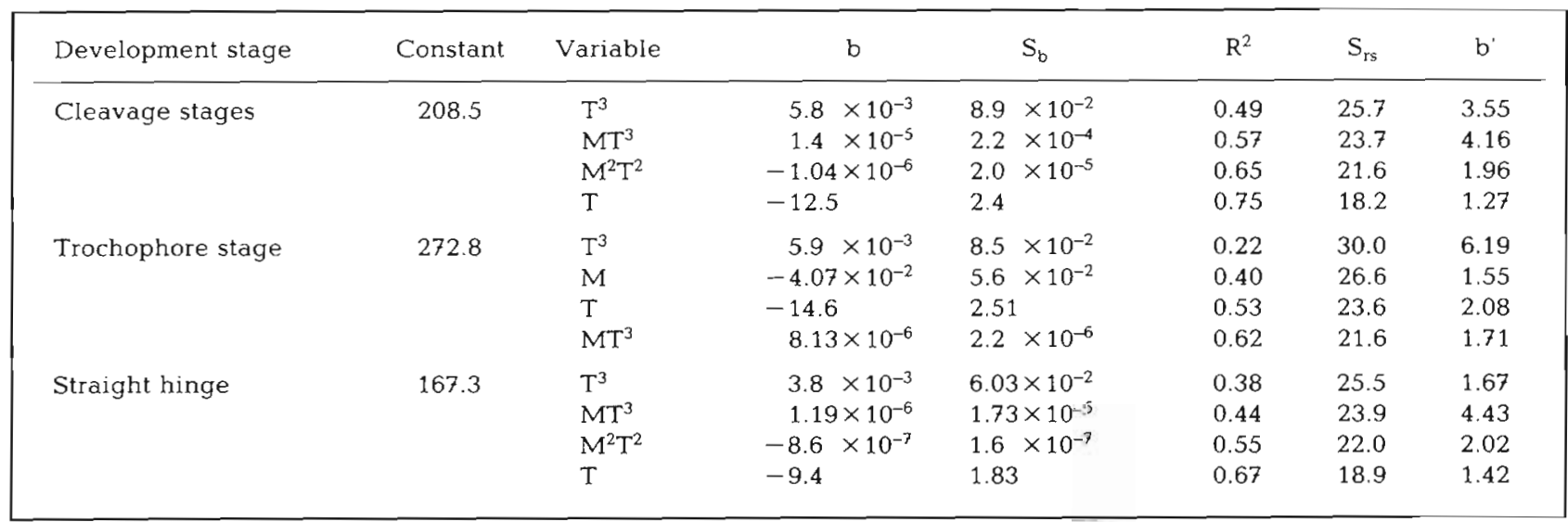

varied between 62 and $75 \%$ when all variables were selected, indicating that most of the variation in mortality can be explained by these variables. Of particular interest is the fact, as for Mulinia (Kennedy et al., 1974a), that the variable $T^{3}$ provides the best single predictor of larval mortality in all 3 developmental stages. Partial regressions (Table 4 ) indicate this variable to be the most useful in estimating or predicting mortality when used in combination with other variables.

In general, the cleavage stages of Argopecten irradians appear to be more sensitive to higher temperatures than the embryonic stage of either Mulinia lateralis or Mercenaria mercenaria and the same is true of straight-hinge larvae where the ranking in terms of increasing temperature sensitivity runs $M$. mercenaria $<<$. lateralis $<A$. irradians (Kennedy et al. $1974 \mathrm{a}, \mathrm{b}$; current work).

In Argopecten irradians, it is apparent in trochophore larvae that a lower temperature survival threshold as well as an upper threshold exists within the experimental temperature range. The significant rise in mortality below approximately $22^{\circ} \mathrm{C}$ is apparently seen only at the trochophore stage, a phenomenon noted to a lesser degree in Mercenaria mercenaria

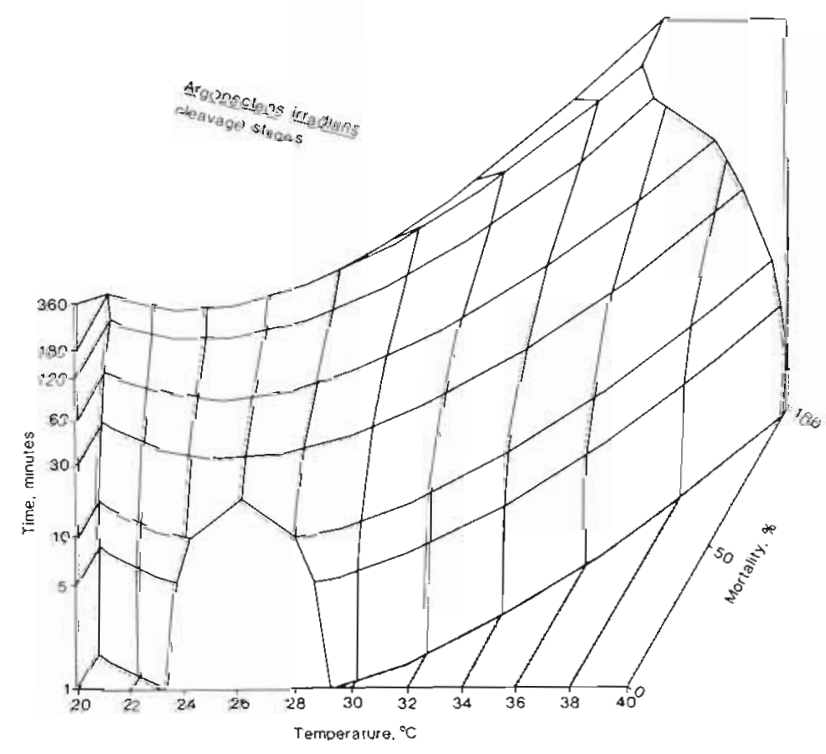

Fig. 1. Argopecten irradians. Time-temperature response surface for cleavage stages

(Kennedy et al., 1974b) and not seen at all in Mulinia lateralis (Kennedy et al., 1974a).

In general Argopecten irradians is the most sensitive of the few species so far subjected to an investigation

Table 5. Argopecten irradians. Analysis of variance of multiple regression of \% mortality on temperature and time for embryos and larvae

\begin{tabular}{|c|c|c|c|c|c|c|}
\hline \multirow[t]{2}{*}{ Source of variation } & \multicolumn{2}{|c|}{ Cleavage stages } & \multicolumn{2}{|c|}{ Trochophore } & \multicolumn{2}{|c|}{ Straight hinge } \\
\hline & $\mathrm{df}^{*}$ & MS * & df ${ }^{*}$ & MS * & $\mathrm{df}^{*}$ & MS " \\
\hline Regression & 4 & $149734^{\cdots}$ & 4 & $11810.97^{\cdots} \cdot$ & 4 & $13087.7 \cdots$ \\
\hline Residual & 59 & 332.5 & 63 & 465.5 & 72 & 359.7 \\
\hline \multicolumn{7}{|c|}{$\begin{array}{l}\therefore \text { df, degress of freedom. Differs between stages as only mortalities up to } 100 \% \text { are included in regression equation } \\
\therefore \text { MS, mean squares } \\
\text {.. Significant at } P<0.001 \text { level }\end{array}$} \\
\hline
\end{tabular}




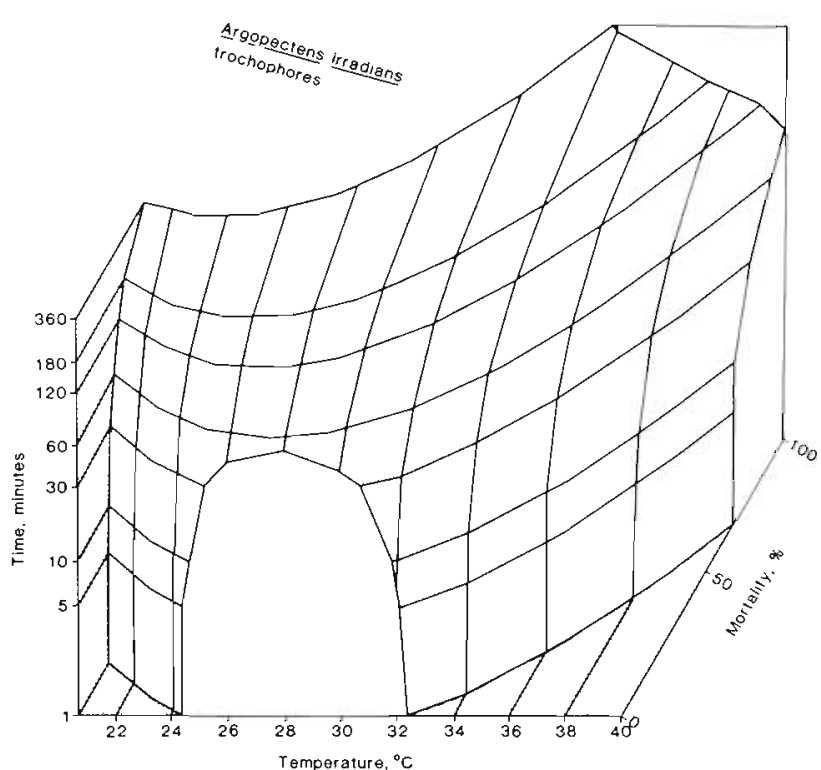

Fig. 2. Argopecten iпradians. Time-temperature response surface for trochophore larvae

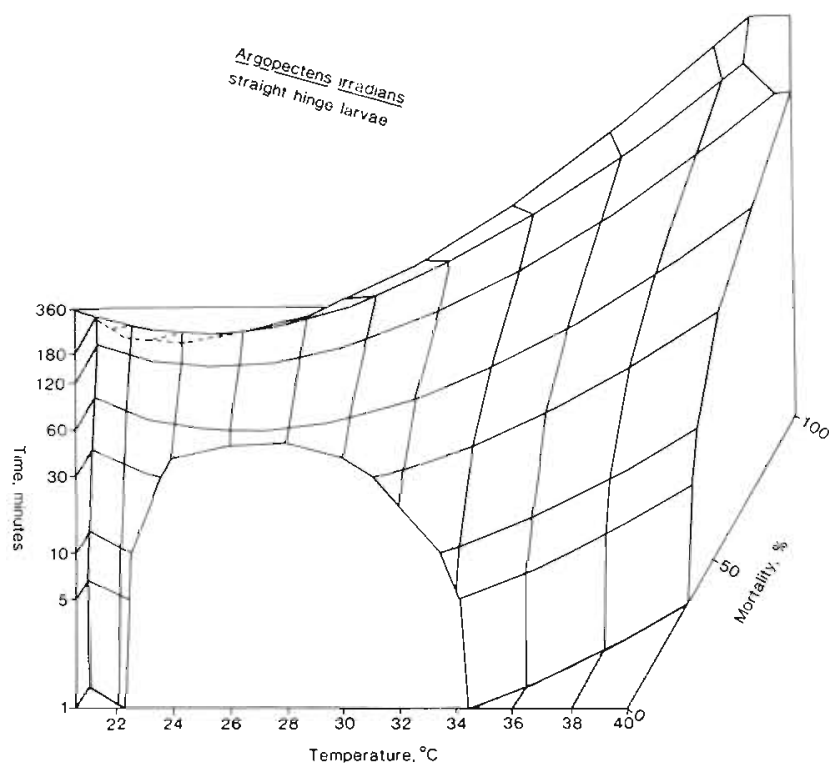

Fig. 3. Argopecten irradians. Time-temperature response surface for straight-hinge larvae

of this kind, including Crassostrea virginica (Hidu et al., 1974), Mulinia lateralis (Kennedy et al., 1974a) and Mercenaria mercenaria (Kennedy et al., 1974b). Over
$80 \%$ mortality in all 3 developmental stages of $A$. irradians may be expected after $30 \mathrm{~min}$ exposure to temperatures near $40^{\circ} \mathrm{C}$. Such temperatures are not unrealistic in an entrainment situation, given Coutants' (1970) estimate that the average temperature increase expected in cooling water would be $10.8^{\circ} \mathrm{C}$ and that summer temperatures in Maryland and Virginia waters regularly reach 28 to $29^{\circ} \mathrm{C}$ (the spawning period for A. irradians in the Chesapeake Bay is MayAugust).

Acknowledgement. We are grateful to Dr. Victor Kennedy for his ideas on experimental design and his critical reading of the manuscript.

\section{LITERATURE CITED}

Calabrese, A., Davis, H. C. (1970). Tolerances and requirements of embryos and larvae of bivalve molluscs. Helgoländer wiss. Meeresunters. 20: 553-564

Coutant, C. C. (1970). Biological aspects of thermal pollution. I. Entrainment and discharge canal effects. CRC Critical Rev. in Environ. Contr. 1: 341-381

Hidu, H., Roosenburg, W. H., Drobeck, K. G., McErlean, A. J., Mihursky, J. A. (1974). Thermal tolerance of oyster larvae, Crassostrea virgincia Gmelin, as related to power plant operation. Proc. natn. Shellfish Ass. 64: 102-110

Kennedy, V. S., Roosenburg, W. H., Zion, H. H., Castagna, M. (1974a). Temperature-time relationships for survival of embryos and larvae of Mulinia lateralis (Mollusca: Bivalvia). Mar. Biol. 24: 137-145

Kennedy, V. S., Roosenburg, W. H., Castagna, M., Mihursky, J. A. $(1974 \mathrm{~b})$. Mercenaria mercenaria (Mollusca: Bivalvia): temperature-time relationships for survival of embryos and larvae. Fish. Bull. U. S. 72: 1160-1166

Koo, T. S. Y., Johnston, M. L. (1978). Larva deformity in striped bass, Morone saxatilis (Walbaum), and blueback herring, Alosa aestivalis (Mitchill), due to heat shock treatment of developing eggs. Environ. Pollut. 16: 137-149

Lucas, J. S., Costlow, J. D. (1979). Effects of various temperature cycles on the larval development of the gastropod mollusc Crepidula fornicata. Mar. Biol. 51: 111-117

Marcy, B. C., Jr. (1971). Survival of young fish in the discharge canal of a nuclear power plant. J. Fish. Res. Bd Can. 28: 1057-1060

Tarzwell, C. M. (1972). An argument for the open ocean siting of coastal thermal electric plants. J. environ. Qual. 1: 89-91

Wallis, R. L. (1977). Some aspects of the thermal tolerance of Trichomya hirsuta (Mollusca: Bivalvia) of Eastern Australia. Mar. Biol. 43: 217-233 